\title{
Intersexual differences in the mudballs of Uca annulipes (Decapoda: Ocypodidae)
}

\author{
Fiona R.L. Burford*, Peter K. McGregor ${ }^{\ddagger}{ }^{\ddagger}$ and Rui F. Oliveira ${ }^{\dagger}$ \\ *Department of Animal Behaviour, Zoological Institute, University of Copenhagen, Tagensvej 16, DK-2200 Copenhagen N, \\ Denmark. ${ }^{\dagger}$ Unidade de Investigação em Eco-Etologia, Instituto Superior de Psicologia Aplicada, Rua Jardim do \\ Tabaco 34, 1149-041 Lisboa, Portugal. ${ }^{\ddagger}$ Corresponding author, e-mail: pkmcgregor@zi.ku.dk
}

\begin{abstract}
This study investigated the features of mudballs produced by male and female Uca annulipes. Both sexes formed mudballs from mud excavated from within the burrow during the final hour of the low tide period. Males placed the centre of the mudball aggregation and the furthest mudball significantly further from the burrow than females. These observations suggest that the placement of male mudballs was not simply a by-product of burrow excavation.
\end{abstract}

Fiddler crabs (genus $U c a$ [Brachyura: Ocypodidae]) inhabit intertidal zones and are active at low tide. They construct burrows as high tide refuges and such burrows are also courtship, mating and incubation sites in many species (Salmon, 1987). At least 14 species of Uca build structures from material excavated from within the burrow (Christy, 1988) and many more place mudballs around the burrow entrance during burrow excavation (P. Backwell, personal communication). Such mudballs have been dismissed as a by-product of burrow excavation (e.g. Crane, 1975) but detailed studies of $U$. tangeri (Eydoux) have identified functions of male mudballs related to reducing intermale aggression (Oliveira et al., 1998), influencing female attraction (Latruffe et al., 1999) and delineating territory boundaries (Burford et al., in press). Studies of U.tangeri began after the observation that features of male mudballs were significantly different from those of females.

The aim of this study was to look for non-random features, particularly intersexual differences, of the mudballs produced by an allopatric population of $U$. annulipes (Milne-Edwards). The mudball arrangements of ten males and ten females were measured on Inhaca Island, Mozambique during February 1999. Measurements were taken at the end of the mudballing phase, defined as occurring when a crab entered its burrow and surfaced without a mudball on three consecutive occasions (Burford et al., 2000), or when the crab entered the burrow and sealed the entrance. The following measurements were taken: the total number of mudballs placed, the distance to the nearest, central and furthest mudballs, and the diameter of eight randomly chosen mudballs from which an average was derived. All summary statistics presented below are mean \pm SE.

No significant differences were found between male and female $U$. annulipes in the number of mudballs made (male: $31.2 \pm 4.7$; female: $21.2 \pm 3.3$ ), mudball size (male: $8.1 \pm 0.3 \mathrm{~mm}$; female: $7.5 \pm 0.4 \mathrm{~mm}$ ), or distance from the burrow entrance to the nearest mudball (male: $3.6 \pm 0.7 \mathrm{~cm}$; female: $3.0 \pm 0.9 \mathrm{~cm}$ ). However, males placed the centre of the mudball aggregation (male: $9.7 \pm 0.8 \mathrm{~cm}$; female: $5.6 \pm 0.8 \mathrm{~cm}$; Mann-Whitney $U$ test: $\mathrm{Z}=2.88, \mathrm{~N}=20, P<0.01$ ) and the furthest mudball (male: $15.0 \pm 2.1 \mathrm{~cm}$, female: $9.9 \pm 1.3 \mathrm{~cm}$; Mann-Whitney $U$-test: $\mathrm{Z}=2.12, ; \mathrm{N}=20, \quad P<0.05)$ at a significantly greater distance from the burrow entrance than females. The distance at which mudballs are placed can be expressed in units of the individual's carapace width to control for size effects including sexual dimorphism. The difference between the sexes in the distance to the centre of the mudball aggregation was significant (male: $6.48 \pm 0.6$ carapace widths; female: $4.2 \pm 0.6$; Mann-Whitney $U$-test: $Z=2.38, \quad \mathrm{~N}=20, P<0.02)$ and the distance from the burrow entrance to the furthest mudball approached significance (male: 10.24 \pm 1.4 carapace widths; female: $7.42 \pm 1.1$; Mann-Whitney $U$-test: $Z=1.62, \mathrm{~N}=20, P=0.1$ ).

A significant difference between the sexes in the distance of the centre of their mudball aggregations and their furthest mudballs was the first piece of evidence for a function of male mudballs in $U$. tangeri (Oliveira et al., 1998). However, it is unlikely that the mudballs of male $U$. annulipes function in the same way as $U$. tangeri as male $U$. annulipes placed mudballs in the last hour of low tide and then entered and plugged their burrows (as did females).

Our results with $U$. annulipes suggest that $U c a$ mudballs merit further study.

This research was funded by the University of Copenhagen and SNF (grant numbers 9701908 and 9801928 to P.K.M.). We thank: Ria Formosa Natural Park, Portugal and Inhaca Island Marine Research Station, Mozambique; colleagues at ISPA, Lisbon, and the Department of Animal Behaviour, Copenhagen; Claire Latruffe and Ellie Davies. Further thanks to José Paula, Patricia Backwell, John Christy and Mike Jennions for advice and comments.

\section{REFERENCES}

Burford, F.R.L., McGregor, P.K. \& Oliveira, R.F., 2000. The sequence of mudball placement by male fiddler crabs, Uca tangeri. Etologia, 8, 53-55.

Burford, F.R.L., McGregor, P.K. \& Oliveira, R.F., in press. Mudballing revisited: further investigations into the construction behaviour of male Uca tangeri. Behaviour.

Christy, J.H., 1988. Pillar function in the fiddler crab Uca beebei. I. Effects on male spacing and aggression. Ethology, 78, 53-71.

Crane, J.H., 1975. Fiddler crabs of the world, Ocypodidae, genus Uca. Princeton: Princeton University Press. 
Latruffe, C., McGregor, P.K. \& Oliveira, R.F., 1999. Visual signalling and sexual selection in male fiddler crabs, $U_{c a}$ tangeri. Marine Ecology Progress Series, 189, 233-240.

Oliveira, R.F., McGregor, P.K., Burford, F.R.L., Custódio, M.R. \& Latruffe, G., 1998. Functions of mudballing behaviour in the European fiddler crab Uca tangeri. Animal Behaviour, 55, 1299-1309.
Salmon, M., 1987. On the reproductive behaviour of the fiddler crab Uca thayeri, with comparisons to $U$. pugilator and $U$. vocans: evidence for behavioural convergence. Fournal of Crustacean Biology, 7, 25-44.

Submitted 10 August 2000. Accepted 29 November 2000. 